\begin{tabular}{|c|c|c|}
\hline Article Info & ARAŞTIRMA MAKALESİ & \\
\hline Title of Article & $\begin{array}{l}\text { Guangming Village and Other Examples: Post- } \\
\text { Disaster Reconstruction in Rural China }\end{array}$ & \\
\hline $\begin{array}{l}\text { Corresponding } \\
\text { Author }\end{array}$ & $\begin{array}{l}\text { Didem Güneş YILMAZ } \\
\text { Bursa Teknik Üniversitesi, Mimarlık ve Tasarım Fakültesi, Mimarlık Bölümü, } \\
\text { didem.yilmaz@ btu.edu.tr }\end{array}$ & \\
\hline $\begin{array}{l}\text { Submission Date } \\
\text { Admission Date }\end{array}$ & 01/03/2019/31/05/2019 & \\
\hline How to Cite & $\begin{array}{l}\text { YILMAZ, D. G., (2018). Guangming Köyü ve diğer örnekler: Afet sonrası Çin } \\
\text { kırsalında yapılaşma, Kent Akademisi, Volume, } 12 \text { (37), Issue 2, Pages, 241-256 }\end{array}$ & $\begin{array}{c}\text { ORCID NO: } \\
0000-0001-8792-051 x\end{array}$ \\
\hline
\end{tabular}

\title{
Guangming Köyü ve Diğer Örnekler: Afet Sonrası Çin Kırsalında Yapılaşma
}

\section{ABSTRACT:}

The transformative effect of the post-disaster permanent housing implementation is well known. As an earthquakeprone country, China has begun to approach more experimentally to the reconstruction of rural settlements particularly following the devastating 2008 Wenchuan Earthquake. Lately, the example of Guangming Village, which was destroyed by the Ludian Earthquake in 2014, was awarded in the World Architecture Festival in 2017. The paper focuses on the Guangming village and the other similar examples in rural China in order to evaluate the experimental approach to the architectural design of rural houses, material selection, participatory construction method and the new urban-look pattern and its social outcomes. The review includes Jintai, Yangliu, Ma'an Qiao, Da Ping and Shengli Villages in addition to Guangming Village.

ÖZ:

Afet sonrası kalıcı konut uygulamalarının 'dönüştüren' etkisi herkesçe bilinmektedir. Deprem ülkesi olan Çin ise, özellikle 2008 yılında yaşadığı yıkıcı Wenchuan Depremi sonrasında kırsal yerleşimlerinde yeniden yapıma deneysel yaklaşımlarda bulunmuştur. Son olarak 2014 yılındaki Ludian depremle yıkılan Guangming'de yeniden inşa edilen bir konut 2017 Dünya Mimarlık Festivali’nde ödüle layık görülmüştür. Yazı, Çin kırsalında afet sonrası 'baştan yaratılan' yerleşimlerin örneklerine yer vermektedir. Yeniden yapımda tercih edilen mimari yaklaşım, malzeme seçimi, katılımcı inşa süreci ele alınmakla birlikte, oluşturulan yeni kırsal yerleşimlerin kent dokusu ile benzerliği değerlendirilmektedir. İncelenen köyler arasında Jintai, Yangliu, Ma'an Qiao, Da Ping ve Shengli köyleri de yer almaktadir.

KEYWORDS: rural China, post-disaster reconstruction, disaster housing, transformation of rural, transformative architecture

ANAHTAR KELIMELER: kırsal Çin, afet sonrası kalıcı konut, afet konutları, kırsalda dönüşüm uygulamaları, kırsal mimarlık.

${ }^{1}$ Bursa Technical University, Faculty of Architecture and Design, Department of Architecture, didem.yilmaz@btu.edu.tr 


\section{“Guangming Köyü ve diğer örnekler: Afet sonrası Çin kırsalında yapılaşma”}

\section{GíRiş:}

Afet sonrası yapılaşma ve kalıcı konut uygulamaları, yıkıma uğrayan bölgenin yapılı çevresinin planlı yapılaşma ile iyileştirilmesini hedeflerken, düşük veya dar gelirli kimliğiyle betimlenen yerel halkın da sosyo-ekonomik durumunun sürdürülebilirlik çerçevesinde daha üst seviyeye çekilerek kalkınmasını amaçlar. Dünyanın en kalabalık ülkesi Çin'de kırsalda bu amaca yönelik olarak yapılan çalışmalar son yıllarda çok ses getirmeye başlamıştır. Her ne kadar dünyada yayılan 'kente göç' hareketinden etkilenmiş de olsa, ülkenin nüfusunun \%43'ü hala kırsal olarak sınıflandırılan yerleşim yerlerinde yaşamaktadır. Ancak, kırsaldaki nüfus artış hızı -\%2 civarındadır (URL 1), yani kentlere hızla göç vermeye devam etmektedir. Bu nedenle, Çin hükümeti kırsal yerleşimleri kalkındırmayı, yerleşim yerleri olarak cazip duruma getirmeyi amaçlamaktadır. Depremler etki alanındaki yerleşimlerde yapılı çevreyi yıkıma uğrattığı için 'yeniden yapım' ihtiyacı doğurmaktadır. Bu da o bölgede ihtiyaç olan düzenli yapılaşma planını harekete geçirmek için gereken imkânı sağlar. Yani, bir firsat penceresi olarak görülür. Yazı, bu kapsamda 2008 yılındaki Wenchuan Depremi (Sichuan Depremi olarak da bilinir) ile başlayan ve Çin hükümeti tarafından desteklenen kırsaldaki dönüşüm hareketinin mimari ve afet sonrası yeniden planlama çıktılarına dikkat çekmekte, yeniden inşa için tercih edilen yerel halkın katılımının hem sosyal hem ekonomik katkılarını irdelemektedir. İncelemeye dahil edilen köyler sırasıyla, Guangming, Yangliu, Jintai, Ma’an Qiao, Da Ping ve Shengli köyleridir.

\section{Guangming Köyü}

Kasım 2017'de Berlin'de düzenlenen Dünya Mimarlık Festivali (WAF) finalinde ilan edilen mimarlık ödülleri arasında en öne çıkanlardan biri deprem sonrasında yeniden inşa edilen Guangming Köyü evleriydi (URL 2). Köy, 3 Ağustos 2014 tarihinde Richter ölçeğinde 6.5 şiddetiyle Çin'in Yunnan Bölgesi'ndeki Ludian eyaletini sallayan ve aynı adla anılan depremde tamamen yıkılmıştı. Ağustos'ta vuran depremin ardından Ekim 2014'te bir grup köye ilk ziyareti gerçekleştirdi ve köylülerin zor koşullardaki yaşamlarından etkilenerek yeniden yapım programını başlatmaya karar verdi. Köy, bölgesel karakteristikler ve yerel mimari doku yeniden ele alınarak Hong Kong Çin Üniversitesi ve Kunming Bilim ve Teknoloji Üniversitesi iş birliğiyle projelendirilip yeniden inşa edilmiştir (URL 3). Depremde çok fazla hasar görmesi ve çoğunluk yapının yıkılmasından ötürü (Şekil 1) geleneksel sıkıştırılmış-toprak duvarlı yapılara ön yargıyla bakılmasına karşın, köyün konumu, hava şartları, zaman kısıtlaması, yerel olmayan beton ve tuğla gibi malzemelerin tedarik edilmesindeki maddi yük ve aynı zamanda yerel iklim şartlarında zayıf yalıtım performansı göstermesi, yerel halkın bu malzemelerle doğru yapım tekniklerini uygulayabilmesindeki soru işaretleri ve benzer sorunlar nedeniyle mimar ve mühendislerden oluşan çalışma grubu geleneksel sıkıştırılmış-toprak duvarlı yapım tekniğinin nasıl depreme karşı dayanıklı olabileceği üzerinden durdu. Çalışmalar sonucunda yerel halkın kolaylıkla anlayıp yapabileceği kare planlı ve piramit çatılı basit bir ev planı ortaya çıkarıldı ve bir örneği inşa edildi. Grubun liderliğini yapan Profesör NG Yan Yung Edward, neden bu yapım tekniği üzerinde durduklarını şöyle açıklıyor (URL 4): “Depremler sadece Çin'in problemi değil, dünya çapında bir problem. Çok fazla insan toprak evlerde yaşıyor. Bu nedenle, eğer bu insanlara daha güvenli bir yapı tasarlamanın bir yolunu bulursanız, belki de neredeyse 100 milyon kişinin sorununu çözmüş olacağız". Yaklaşık 150 metrekare olan yapı planda iki parçaya ayrılıyor. Ortadaki açık mekân (Şekil 2) sadece doğal 1şık amaçlamıyor, aynı zamanda yaz mevsiminde gölgelik ve serinlik, kış mevsiminde ise sıcaklığın evin tüm içine kolayca yayılmasını sağlayan bir geçiş hacmi oluyor (Şekil 3). Profesör Ng, bu mimari yansıyışı şöyle vurguluyor: "En önemli şeylerden biri, sadece bir ev inşa etmek değil, kullanıcılarının memnuniyetle kullanacă̆ bir yapı inşa etmektir". 2014 depremiyle oluşan motivasyonuyla başlattığı "Bir Üniversite Bir Köy Projesi” kapsamında Profesör Ng öğrencileriyle birlikte yardım ve araştırma çalışmalarını sürdürmekte olup (URL 5), yakın geçmişte ülkemize gelip deneyimlerini paylaşmıştır (Aktuelarkeoloji, 2018).

Yapının ödül almasında jüri raporuna göre, tasarımın sıradan insanların yüzleşmek zorunda kaldığı sorunlara çare bulması, geleneksel yapı malzemesi ve yapım tekniğinin yeni teknolojilerle ve günümüzün know-how birikimini kullanarak harmanlanması ve bulunan çözümün deprem riski altında yaşayan düşük gelir düzeyinden pek çok yere adapte edilebilir olması rol oynadı. Bir başka açıdan ise, bu yapı, mimarlığın en zenginlerle ilişkili olduğu kadar en dar gelirli kitleler ile de ilgili olduğunu göstermiştir (URL 6). Yapının kazandığı tek ödül bu olmayıp, öncesinde Temmuz 2017'de, Architectural Review House Awards kazanmıştır. Jüride yer alan İngiliz mimar Tony Fretton, yapının neden ödül aldığını şöyle yorumlamıştır (URL 7): “Depreme dayanıklı ev tasarımı konusundaki araştırmanın önemi inkâr edilemez, ancak esas etkileyici olan mekânsal kalite ve malzeme kullanımı. Tümüyle yerel toplumu derinden anlayan bir mimarlı̆̆ın yansıması olmuş". Yapı, Aralık 2017'de ise ikincisi düzenlenen CIC Construction Innovation Award töreninde Local Grand Prize Award'a layık görülmüştür. 


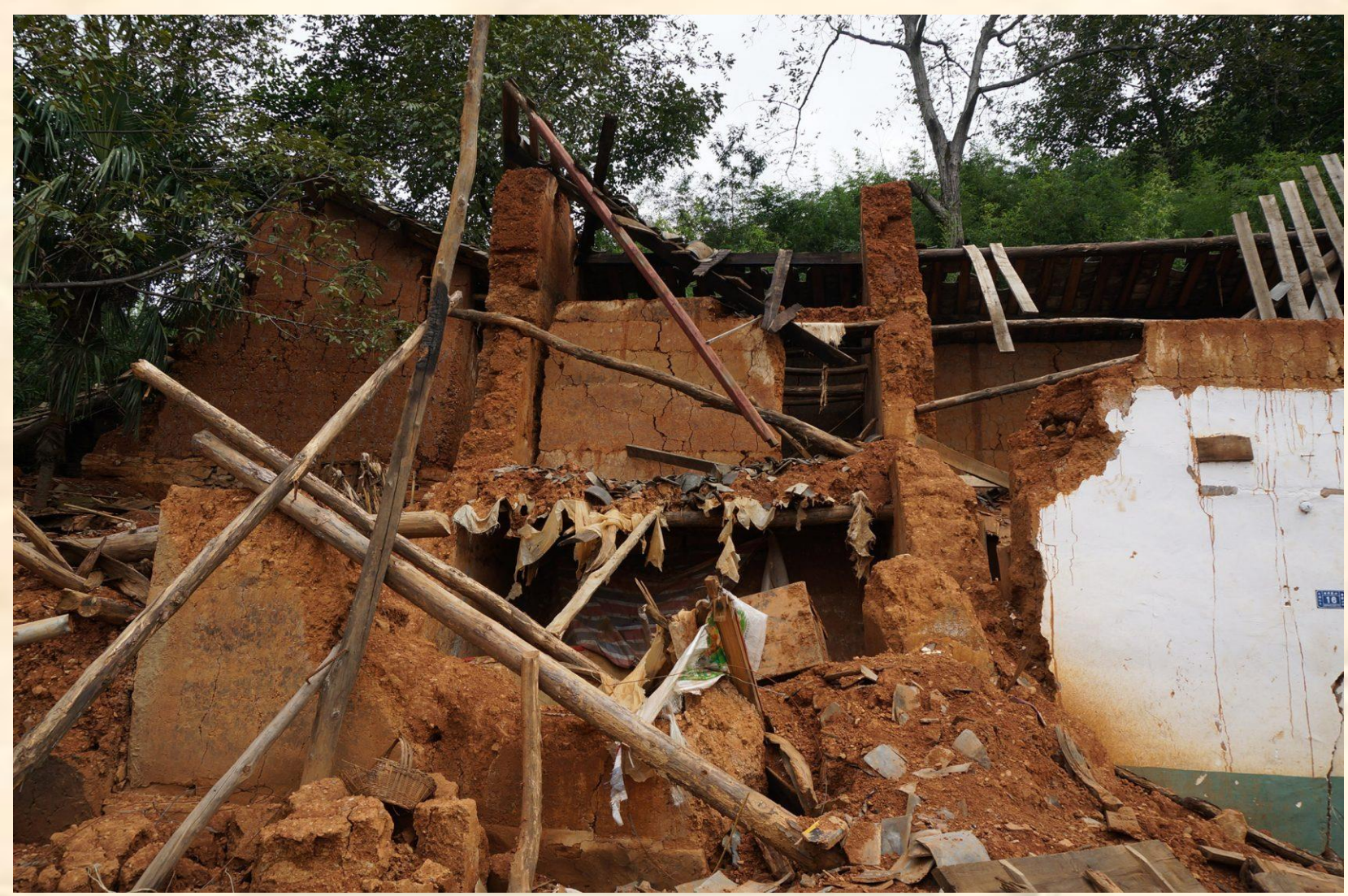

Şekil 1: 2014 Ludian Depremi, Guangming Köyü'ndeki geleneksel toprak yapılara büyük zarar verdi (https://www.dezeen.com/2017/12/01/movie-waf-world-building-of-year-winner-earthquake-resistant-video/ )
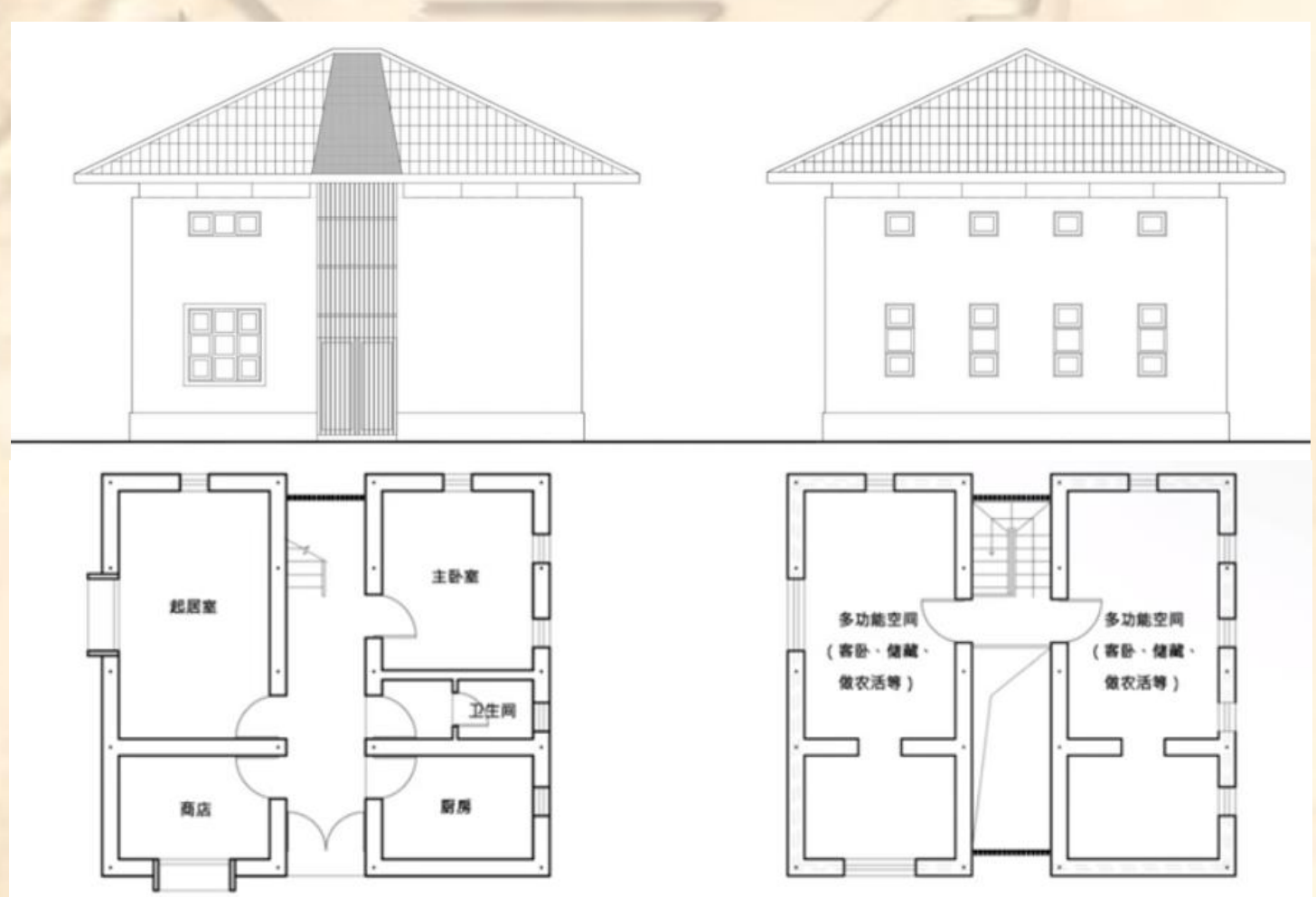
Şekil 2: Depreme dayanıklı olarak tasarlanan ve inşa edilen örnek ev projesi

(https://www.dezeen.com/2017/12/01/movie-waf-world-building-of-year-winner-earthquake-resistant-video/).
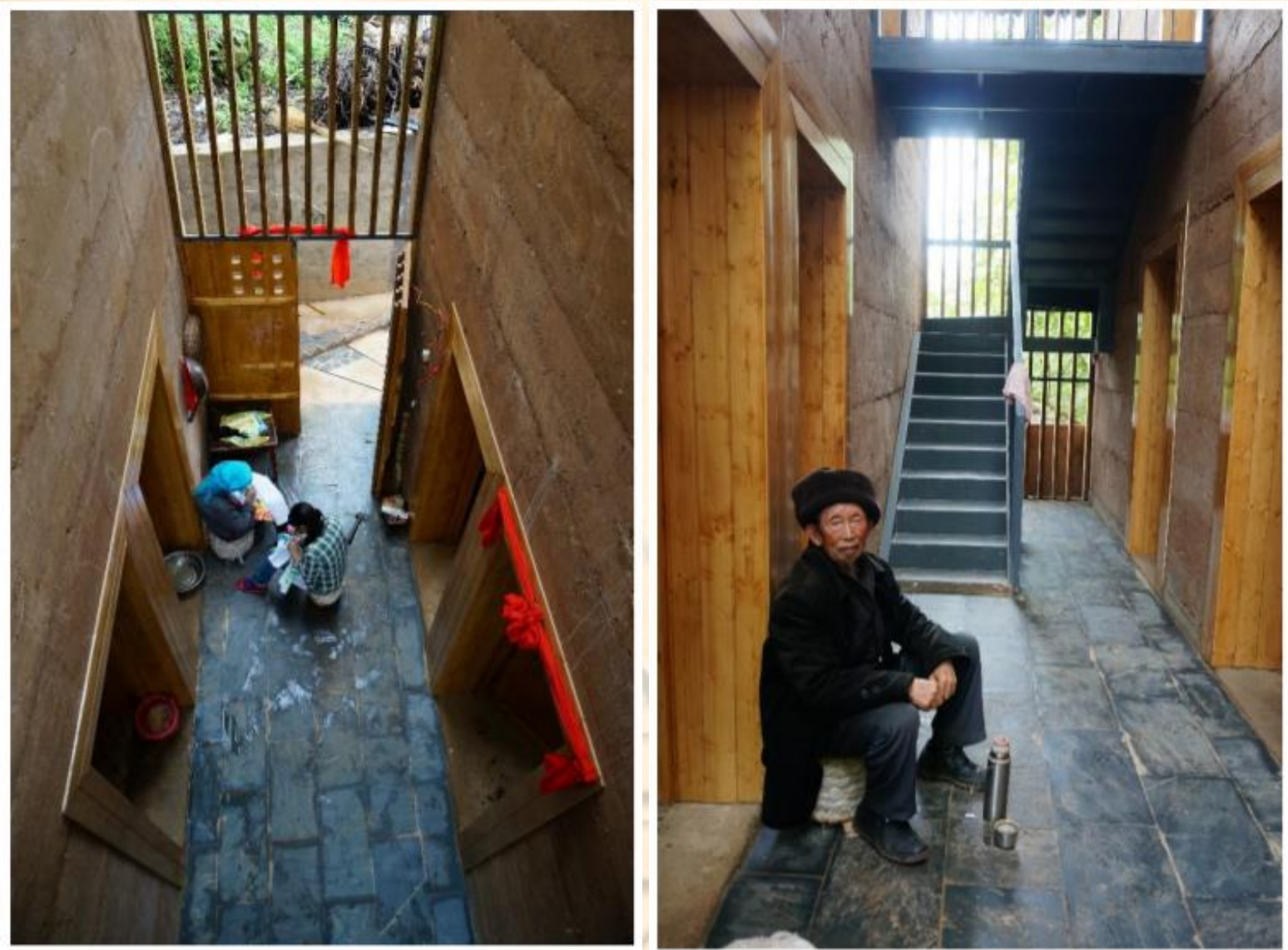

Şekil 3: Depreme dayanıklı evin orta 1şıklık mekânı: giriş kapısı ve üst kata çıkan merdivenler burada yer alıyor (http://web5.arch.cuhk.edu.hk/server1/staff1/edward/www/1u1v/files/CUHK/site_Guangming.html).

\section{Jintai Köyü}

Bir deprem ülkesi olan Çin'de başka birçok farklı nitelikte deprem sonrası kalıcı konut çalışmaları bulunmakta. Hatta, bu konuda özellikle 2008 yılındaki Wenchuan Depremi'nden sonra kırsal bölgelerde oldukça deneysel ilerlediğini söylemek mümkün. Onlardan biri de 2008 yılındaki depremden etkilenen Jintai Köyü. Dağlık bir bölgede yer alan köyde afet sonrası yeniden yerleşim planının ve konut tipolojisinin tasarlanmasında Hong Kong Üniversitesi çatısı altında bulunan ve gelir amaçlı olmayan Curry Stone Tasarım Ödülü'nü kazanmış (XXI, 2016) bir mimari stüdyo olan Rural Urban Framework (RUF) kurucuları Joshua Bolchover ve John Lin rol aldı (URL 8; URL 9). Yeniden inşa çalışmaları sürerken 2011 yılında bu kez de toprak kayması ve sel baskını köyü etkiledi. Köyde 22 adet konut ve bir halk merkezi tasarlandı. Yeni konutlarda, depremden sonra yapılan yüzlerce sıradan konuta karşı yeni bir yaklaşım arandı. Yeşil teras çatı, bio-gaz kullanımı, yağmur suyu kullanımı, gri su kazanımı ve en önemlisi de geçim kaynağı olan kümes hayvancılığını tanıyan bir düzenleme amaçlandı. Alışılagelen köy evlerinden çok farklı duran bu mimari yaklaşımın (Şekil 4) nedenini ise mimarlar, inşa edilebilecek alanın az olması ve bu karşın konut ihtiyacı olan aile sayısının çok olması (Şekil 5) olarak açıklıyor. Yine de metrekare olarak büyüklüğüne, çatı tipine ve işlevine göre dört farklı yapı tipi çıkarabilmişler.

Özellikle, basamaklı çatılar köylülere daha fazla ekin yapabilecekleri alan sağlamak amacıyla tasarlanmış. Betonarme taşıyıcı çerçeve ve tuğla dolgu duvarlardan oluşan konutlar birlikte küçük ölçekli bir kentsel yerleşimi andırıyor. Ancak bu ne tesadüf ne de salt mimarların kendi isteği olan bir durum. 2000'li yılların başlarından beri şiddetle nüfus kaybeden köyleri için Çin mevcut dönüşüm planlamasında (URL 10), kırsal bölgelerinde yaşayan yaklaşık 700 milyon nüfusu, 2030 yllına kadar buna benzer şekilde tasarlanan mini-kentlerde yaşatmayı hedefliyor (URL 11). 


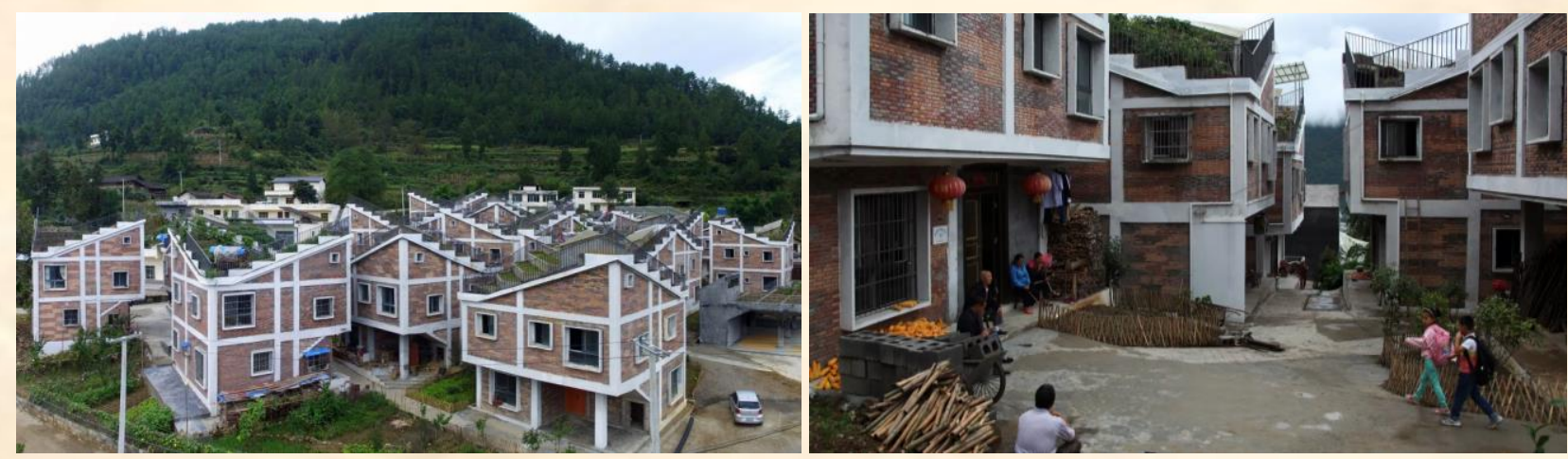

Şekil 4: Deprem sonrası baştan yaratılan Jintai Köyü’nün yeni görüntüsü ve 'sokakları'

(https://www.dezeen.com/2017/10/21/rural-urban-framework-builds-post-disaster-housing-china-rooftop-farms/)

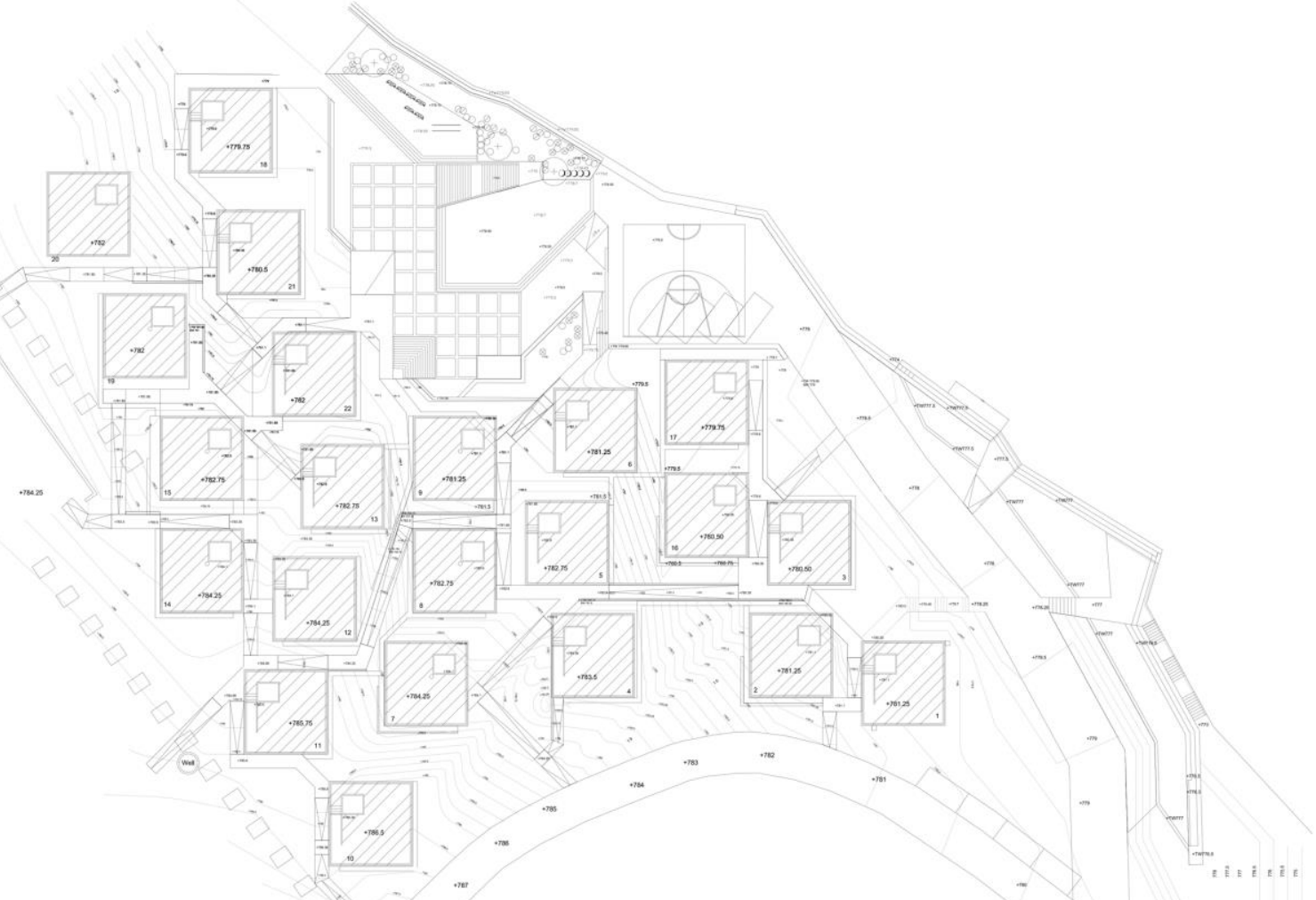

Şekil 5: Jintai Köyü yerleşim planı

(https://www.dezeen.com/2017/10/21/rural-urban-framework-builds-post-disaster-housing-china-rooftop-farms/).

\section{Yangliu Köyü}

2008 depremiyle yeniden inşa edilen bir diğer örneğimiz Yangliu Köyü. Köy, geçmişi neredeyse 3000 yıl öncesine uzanan bir etnik grup olan Qiang mensuplarının yaşadığı köylerden sadece biriydi ve depremde çok fazla zarar görmüştü. Mayıs ayındaki depremin ardından çok geçmeden Temmuz ayında köyün yeniden planlanmasına ait çalışmalar başlatıldı. Bunun için konuyla yakından ilgili Tayvanlı mimar Hsieh Ying-Chun ile çalışıldı. Mimar 1999 yılında ülkesini vuran depremden sonra çalışmalarını bu konuda yoğunlaştırmış. En önemli işlerinden biri de 2010 yılında Tayvan'ın güneyini vuran Morakot Tayfunu'nda yerle bir olan kırsal yerleşimlerde 700'den fazla konutun yeniden projelendirilmesi ve inşasını tamamlamış olmasıdır (URL 12). Yaptığı bu çalışmalar neticesinde 2011 yılında Curry Stone Design Prize (URL 13) ödülüne layık görülmüștür. Oldukça basitleştirilmiş yapım tekniklerine dayalı 
hafif çelik çerçeve strüktür (Şekil 6) ve yerel malzemeleri de duvar, cephe ve çatı için kullanarak başta konut projeleri tasarlayan mimara göre bu yaklaşım sadece maliyeti düşüren bir amaç gütmüyor, aynı zamanda afetten etkilenen insanların köylerinin yeniden inşası sürecine dahil olarak onların acılarını hafifleten bir terapi görevi üstleniyor. Hsieh, afet sonrası konut alanlarının yeniden planlanmasında afetzedelere 'alıcı' gözüyle bakılırsa o projenin bir başka 'afet' olarak sonuçlanacağını savunuyor (URL 14). Yangliu Köyü için de aynı yaklaşımı benimseyen mimar, afet sonrası evsiz kalan yaklaşık 350 kişi için 56 konut planladı (URL 15). Yapımı bir senede tamamlanan evlerin ilk kat duvarları yerel olarak elde edilen kesme taşlardan, ikinci kat duvarları betonarme olarak ve çatı katı duvarları ise ahşaptan inşa edilmiş (Şekil 7) (URL 16). Köy, şimdiye kadar afet sonrası konut çalışmalarını konu alan iki kitaba dahil edilmiştir:

-Design Like You Give a Damn -2: Building Change from the Ground Up (2012), 96-99.

-Humanitarian Architecture: 15 Stories of Architects Working After Disaster (2014), 37-40.
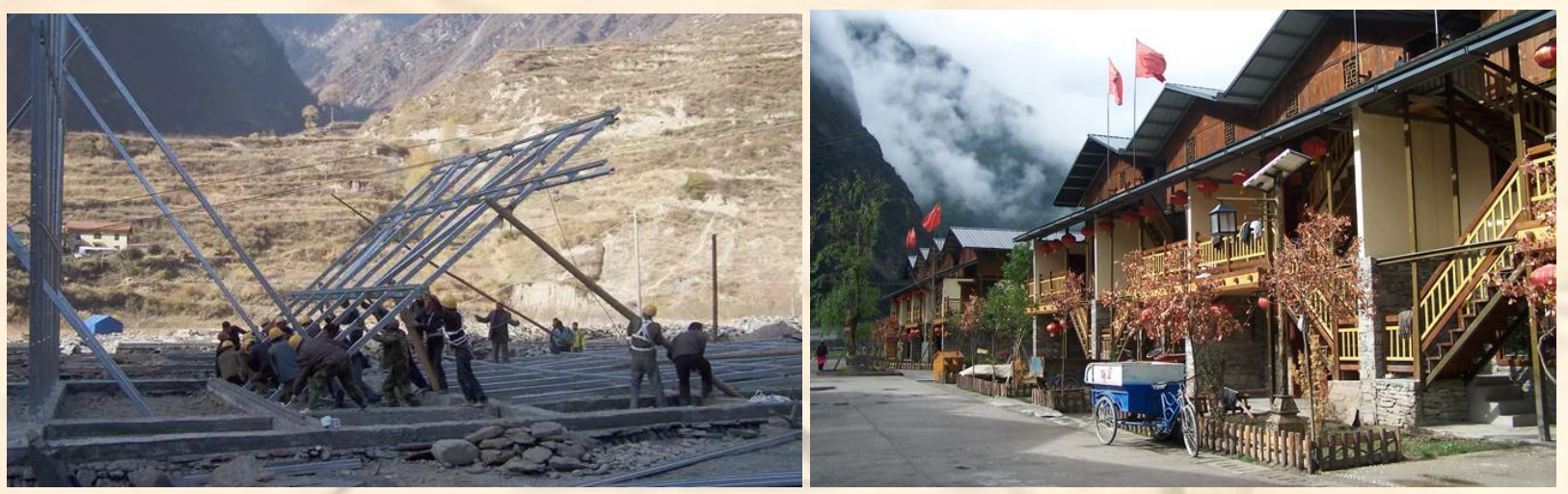

Şekil 6: Evlerinin inşasında görev alan Qiang'lar, bir hafif çelik çerçeve elemanı ayağa kaldırırken.

(Sol: https://www.architectureforpeople.org/architects/hsieh-ying-chun/

Sağ: https://www.architecturalrecord.com/articles/8521-yangliu-village-housing?v=preview ).
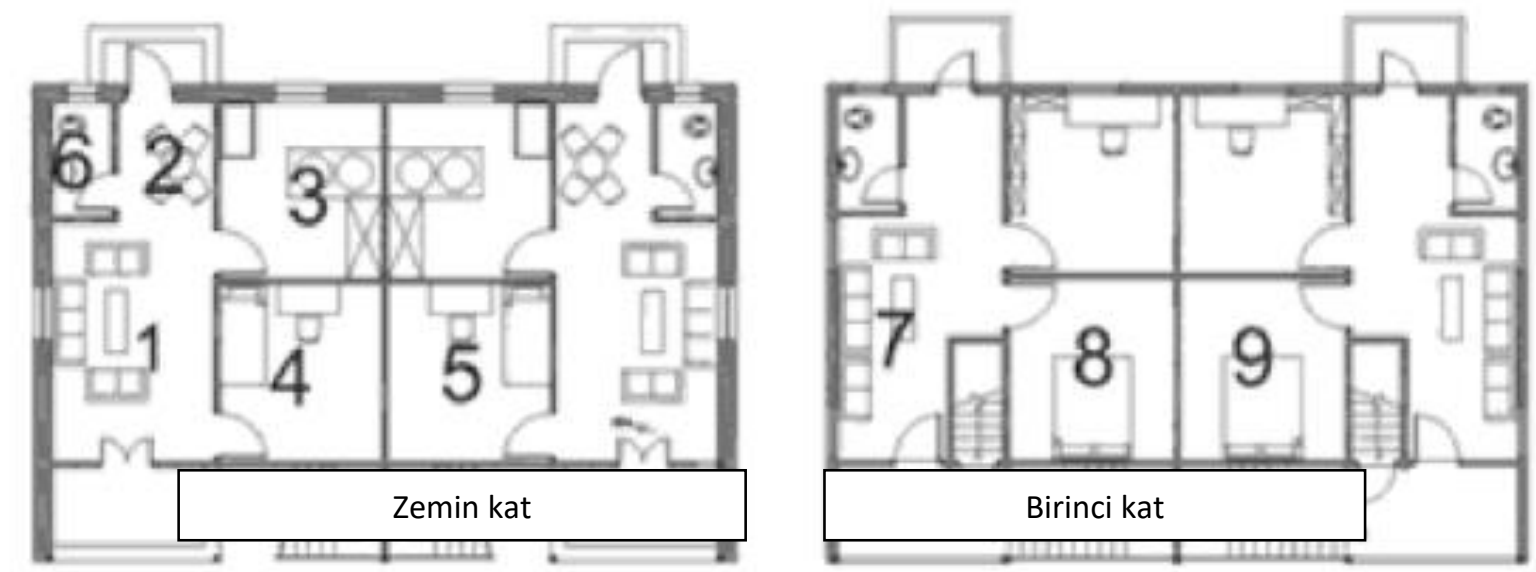
1. Oturma odas 1
2. Yemek odas 1
3. Mutfak
4. Yatak odas1
5. Yatak odas1
6. Banyo
7. Rekreasyon alanı
8. Yatak odas1
9. Yatak odas1
10. Çalışma odası
11. Depo 


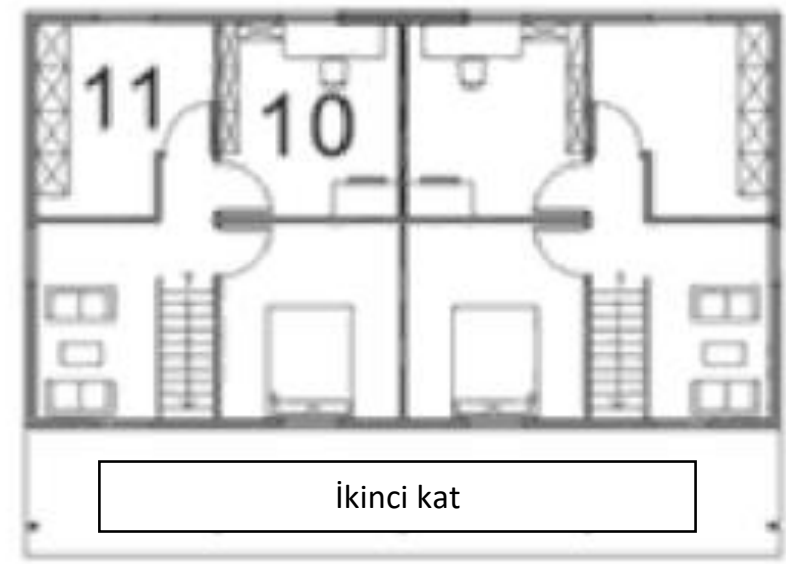

Şekil 7: Evlerin kat planları (Charlesworth, 2015, pp:40).

\section{Ma'an Qiao Köyü}

Ma'anqiao Köyü, 2008 depreminden ağır şekilde etkilenen bir diğer köy. Binden fazla kişinin yaşadığı 272 hanesinden 263'ü kullanılamaz duruma gelmişti (URL 17). Köydeki bütün evler geleneksel sıkıştırılmış toprak duvarlı olup hem konut hem de ahır ünitelerini bir arada barındırıyordu. Ancak, depremden sonra köyün konum olarak çok dağlık oluşu, ulaşım elverişsizliği ve yapım malzemelerinin tedarik zorluğu gibi sebeplerden dolayı yeniden yapımına alışıldık baştan-yarat yöntemiyle değil de bu kez devlet desteğiyle (Konut ve Kentsel-Kırsal Kalkınma BaşbakanlığıMoHURD) başlatılan deprem sonrası geleneksel yöntemlerle depreme dayanıklı yapım temsilinin açık bir laboratuvarı haline getirilmiştir (URL 18). Burada amaç ulaşılabilir yerel malzeme ile hem ekolojik hem sürdürülebilir hem de doğru yapım bilgilerinin gelecek nesillere uygulamalı olarak aktarılmasını sağlamaktı. Hasar görmüş olan yapılardaki hatalar incelenerek ve birkaç prototip üzerinde testler yapılarak, sıkıştırılmış toprak duvarlı strüktürde iyileştirmeler yapıldı. Bunlar, duvardan duvara açıklığın ve döşemeden döşemeye yüksekliğin azaltılması, ahşap köşe kolonlarının ve bambu ağacından halka kiriş eklenmesi ve ayrıca duvar harcına sertliği arttırmak için kireç eklenmesiydi.

Yıllık kişi başı geliri 85-120 euro arasında olan ve Çin'in en fakir bölgelerinden birinde yer alan köy halkı için, 200 euro'luk devlet desteğiyle yapılan üç-açıklıklı betonarme-tuğla tek katlı yapı hem ihtiyaçlarına yönelik yeterli değildi hem de yapımı zorluklar nedeniyle uzun sürecekti. Tercih edilen bu yöntemle ise köy halkının yapım sürecinde yer almasıyla üç ay gibi kısa bir zamanda 33 konutun yeniden yapım süreci tamamlandı. Bir diğer kazanım ise, yıkılmış olan binaların kullanılabilir durumda olan malzemelerinin yeniden değerlendirilerek, enkaz kalıntılarının azaltılmasıydı (Mu vd., 2011). Ayrıca, yaşam başladıktan sonra yapılan termal ölçümlerde eskiye göre daha iyi mevsimsel yalıtım sağlandığı görülmüştür. Projesinde Guangming Köyü’nde ismini gördüğümüz Profesör Edward Ng'nin yer aldığı Ma'anqiao Köyü de birçok ödüle layık görülmüş olup, en önemlileri 2011 yılında verilen UNESCO Asia Pacific Heritage Award (Jüri İnovasyon Ödülü) ve TERRA Award LAUREATE (Mimarlık ve Yerel Kalkınma Kategorisinde Birincilik). 


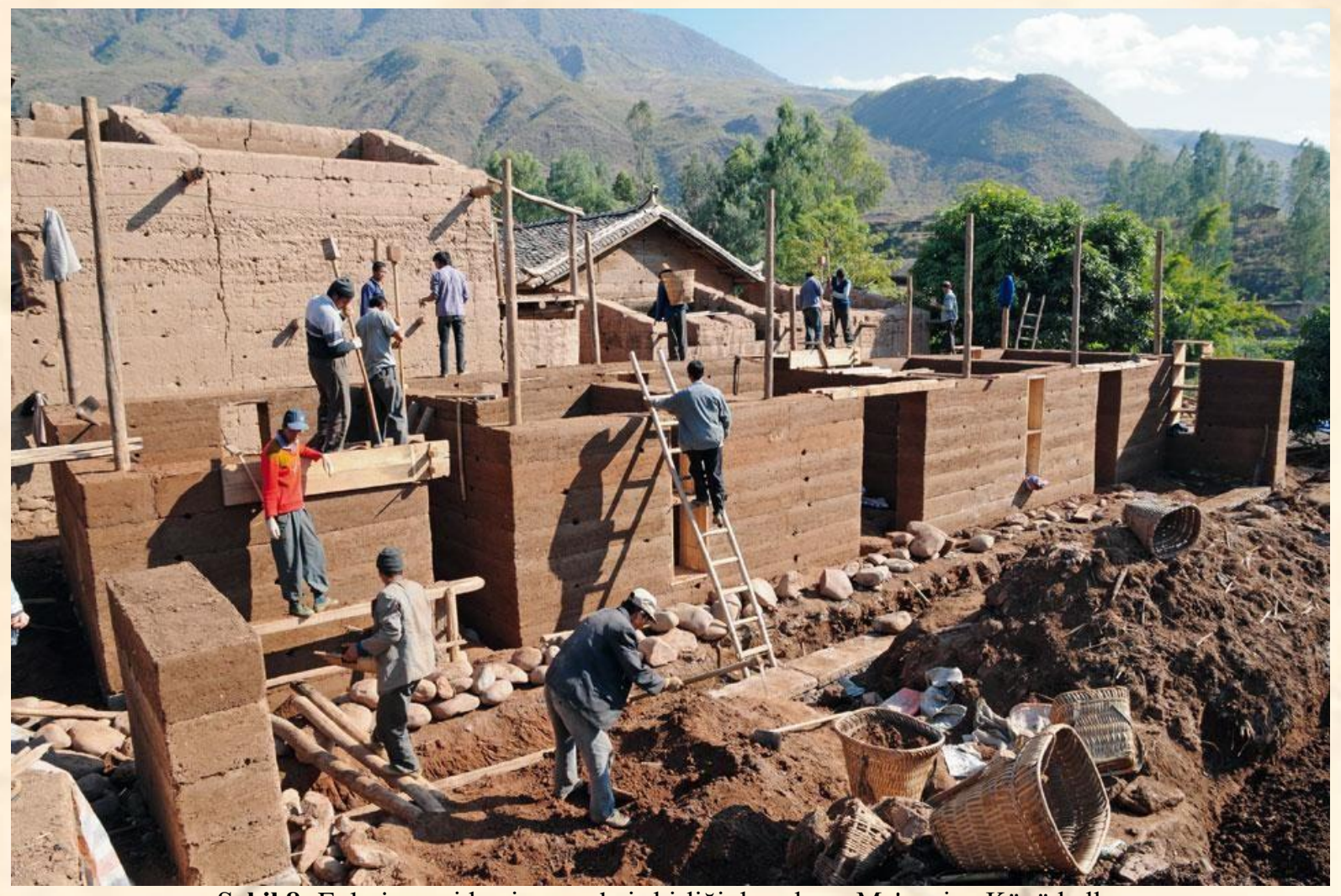

Şekil 8: Evlerin yeniden inşasında iş birliğiyle çalışan Ma'anqiao Köyü halkı.

(https://www.domusweb.it/en/architecture/2012/04/10/back-to-earth.html).

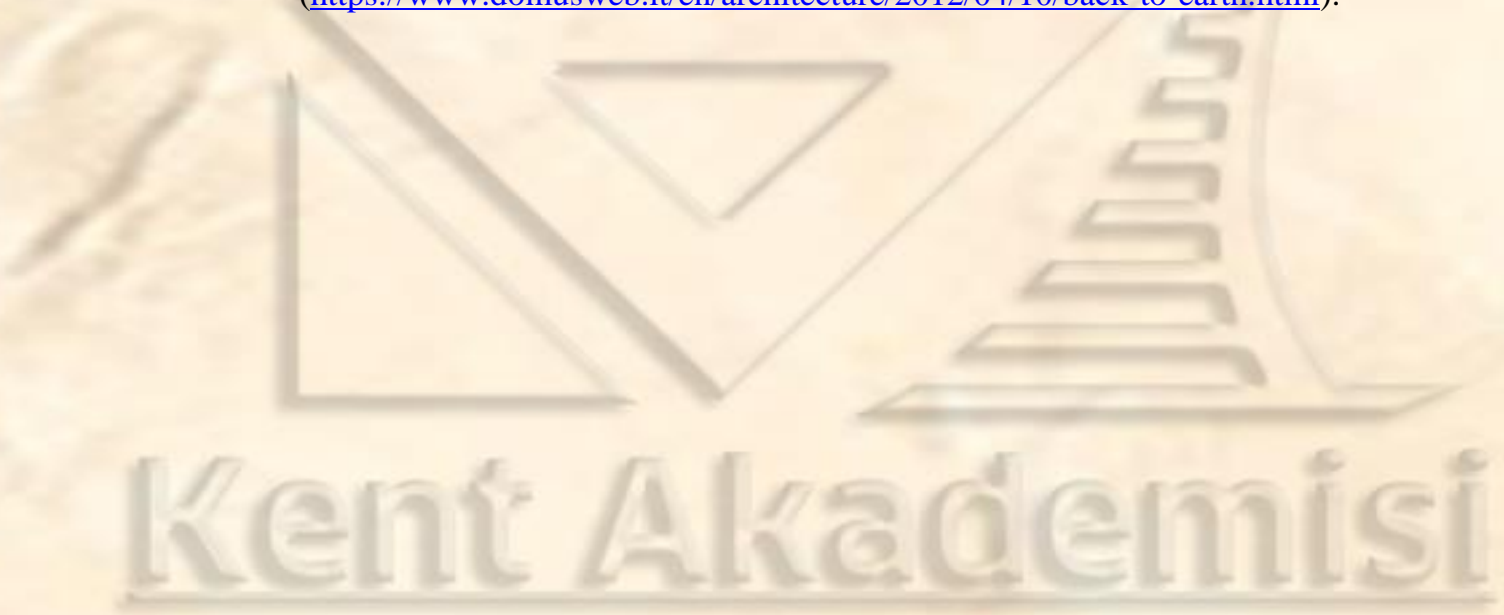




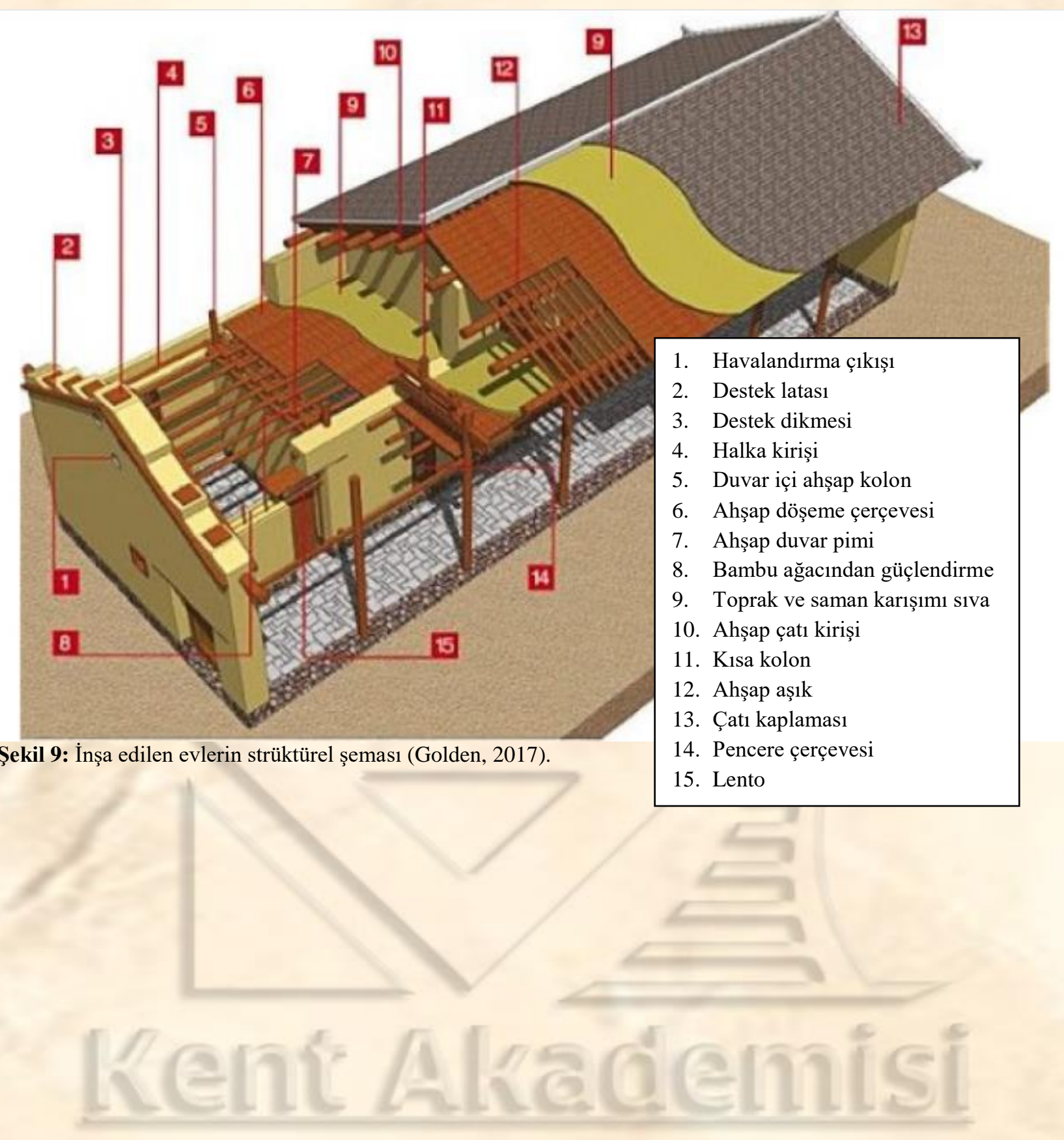




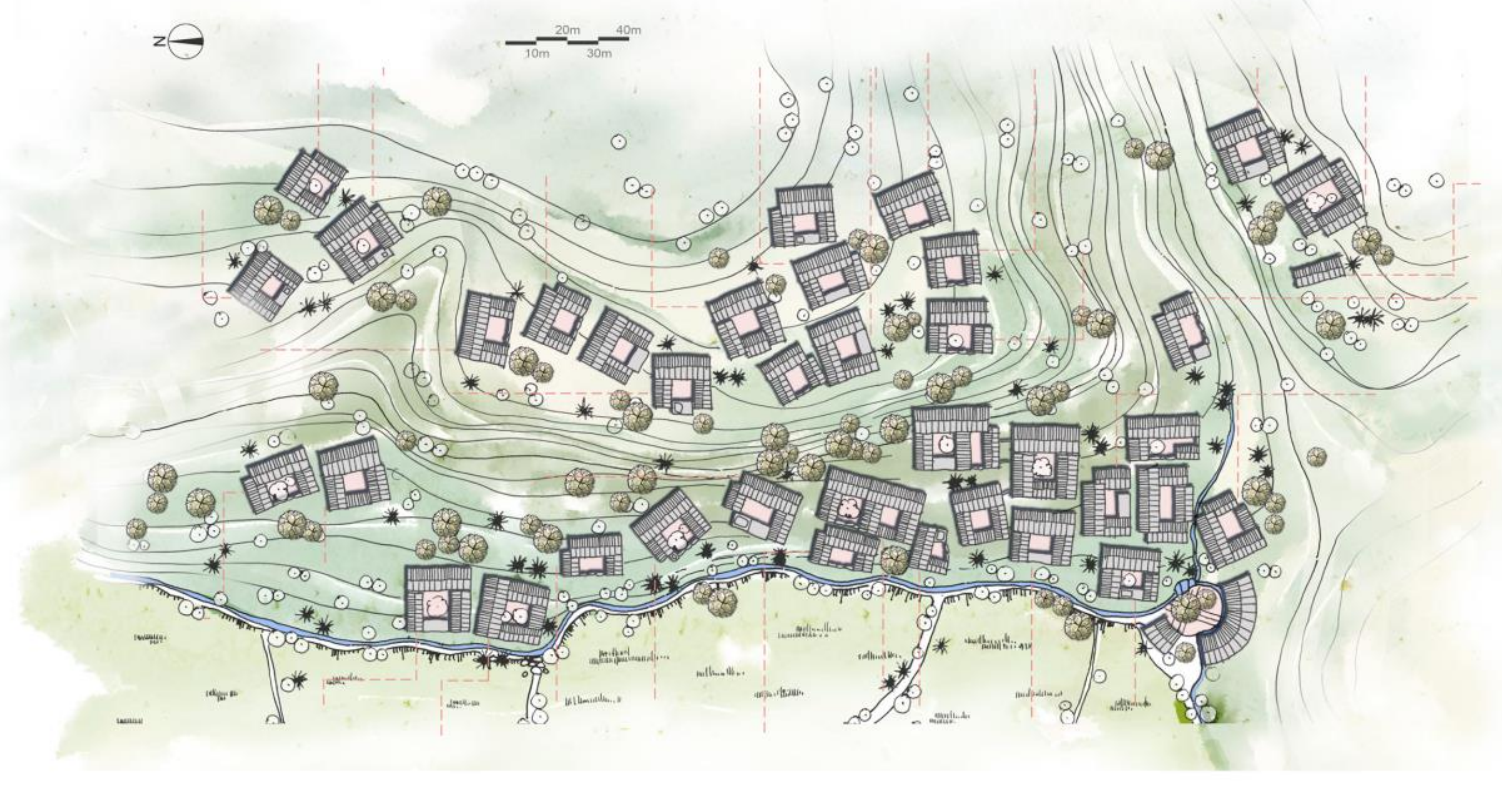

Şekil 10: Ma'anqiao Köyü'nün yeni vaziyet planı

(http://terra-award.org/project/post-earthquake-village-reconstruction-laureate-architecture-local-development/).

\section{Da Ping Köyü}

2008 depreminin merkez üssünden yaklaşık 30km mesafede bulunan Da Ping Köyü de büyük çapta hasar gören ve sonrasında akademik iş birliğiyle inşa edilen köylerden biri. Depremin merkezine çok yakın olmasına ve yapıların çoğunun yerle bir olmasına karşın can kaybı, depremin olduğu saatte köylülerin pirinç tarlalarında çalışmada olmasından dolayı sadece bir kişi olmuştur (URL 19). Köyün yeniden inşası için the Xi'an Mimarlık ve Teknoloji Üniversitesi bünyesinde bulunan bir araştırma merkezi olan Green Building Research Centre (GBRC) yürütücülük yapmıştır. Köyün yeri değiştirilmeden 200 'den fazla konut ve 11 adet köy halkının ortak kullanabileceği birim inşa edilmiştir. Yeniden inşa ve rehabilitasyon sürecinde 5 adımlı bir sistem uygulanmış, tasarıma geçilmeden önce yerel iklim koşulları ve köy sakinlerinin mekânsal ihtiyaçları bilgileri toplanmış ve konutlar sahiplerine teslim edildikten sonra da kullanıcı memnuniyet anketleri ve ısısal konfor analizleri yapılmıştır. Her ailede kişi başı ortalama 35 metrekare üzerinden mekânsal alan hesaplanmış ve modüler bir plan ile ailelerin nüfusuna ve geçim kaynağına dayalı olarak yapı tasarlanmıştır. Kırsal nüfusun ekonomik zorlukları nedeniyle, maliyeti azaltmak için farklı yöntemler denemiştir. Başta, yerel malzeme olarak kolaylıkla temin edilebilen bambu ve diğer ağaç türleri ve yerel halk tarafından bilinen bir yapım yöntemi olan ChuanDou (Fu, 2017) olarak bilinen ahşap çerçeve sistemi kullanılarak yerel insan gücünden faydalanılması sağlanmıştır. ChuanDou sisteminde strüktürel olarak beş adet ince kesitli ahşap kütükler yerden doğruca çatıya kadar iki kat boyunca yükselir ve arada yatay elemanlardan çatıya yükselen altı adet ara dikey kütüklerle çatı makası oluşturulur (Knapp, 2000; s:84). Ayrıca, yıkılmış olan yapıların kullanılabilir ahşap, taş vb. parçalarından faydalanılmıştır. İnşa sırasında köylüler gruplar haline sadece başlarındaki mühendislerin kontrolü ve danışmanlığında çalışmışlardır.

Tüm bunlar sayesinde maliyet metrekare başına ortalama 76 \$'a kadar düşürülmüş, yine ortalama olarak bir konutun yeniden inşasının maliyetinin yarısı konut sahibi tarafından yarısı da Çin hükümeti ve uluslararası maddi yardımlarla karşılanmıştır. Maddi açıdan birikimi olmayan ve meblağı karşılayamayan ev sahiplerine yine devlet tarafından faizsiz kredi desteği verilmiştir. İnşa edilen ortak alanlardan biri de 610 metrekare alana sahip halk merkez binasıdır. İçinde okuma odası, satranç odası, 200 kişinin toplanabileceği faaliyet ve toplantı odaları bulunmakta. Belirli bir süre bu merkezde köylülerin etkili tarım, ilk yardım ve doğru inşa yöntemleri konularında eğitim alabilecekleri seminerler de düzenlenmiştir. 


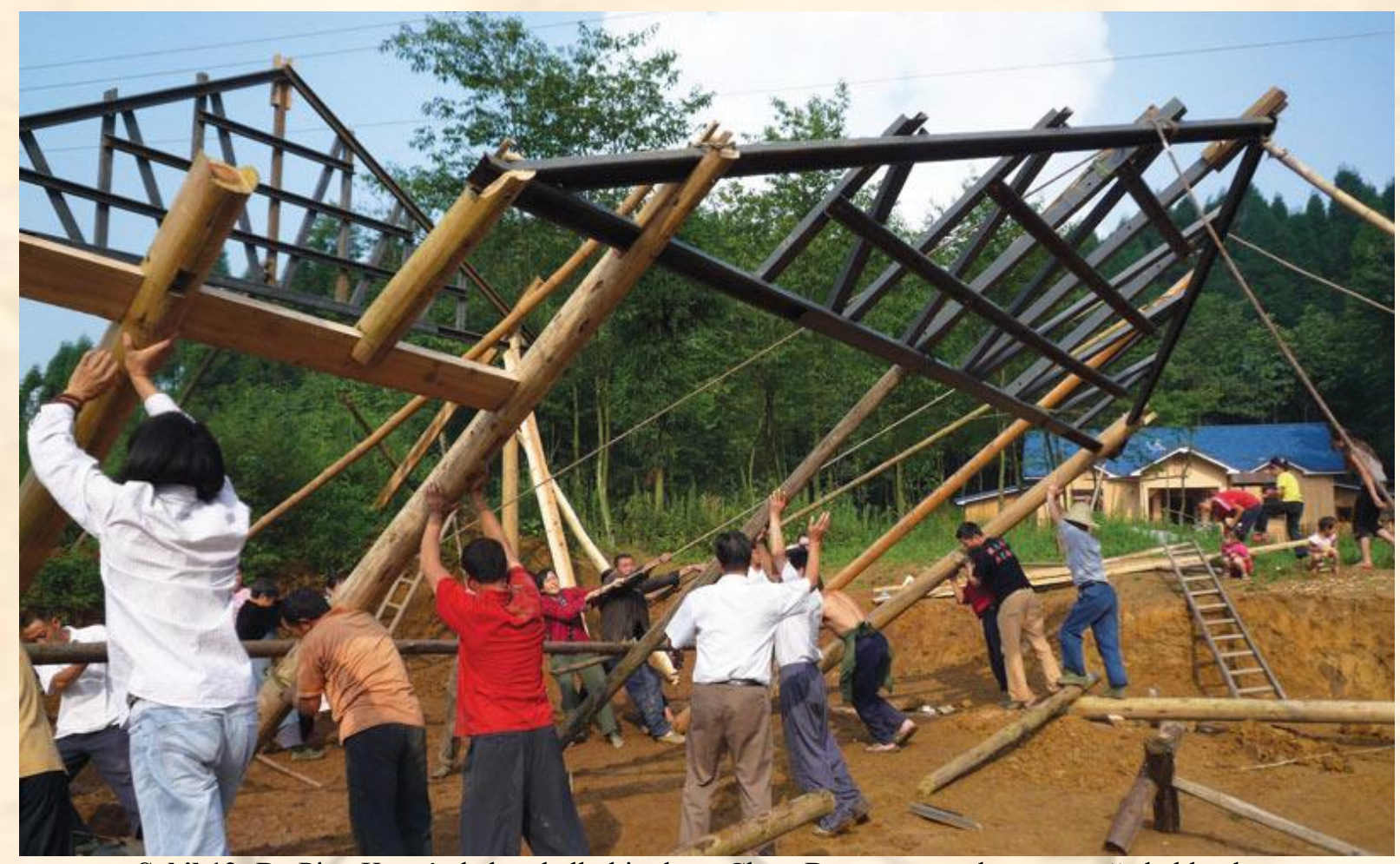

Şekil 12: Da Ping Köyü’nde köy halkı bir ahşap ChuanDou çerçeve elemanı ayağa kaldırırken

(https://www.world-habitat.org/world-habitat-awards/winners-and-finalists/sustainable-village-post-earthquakereconstruction-and-rehabilitation-in-da-ping-village-sichuan/)
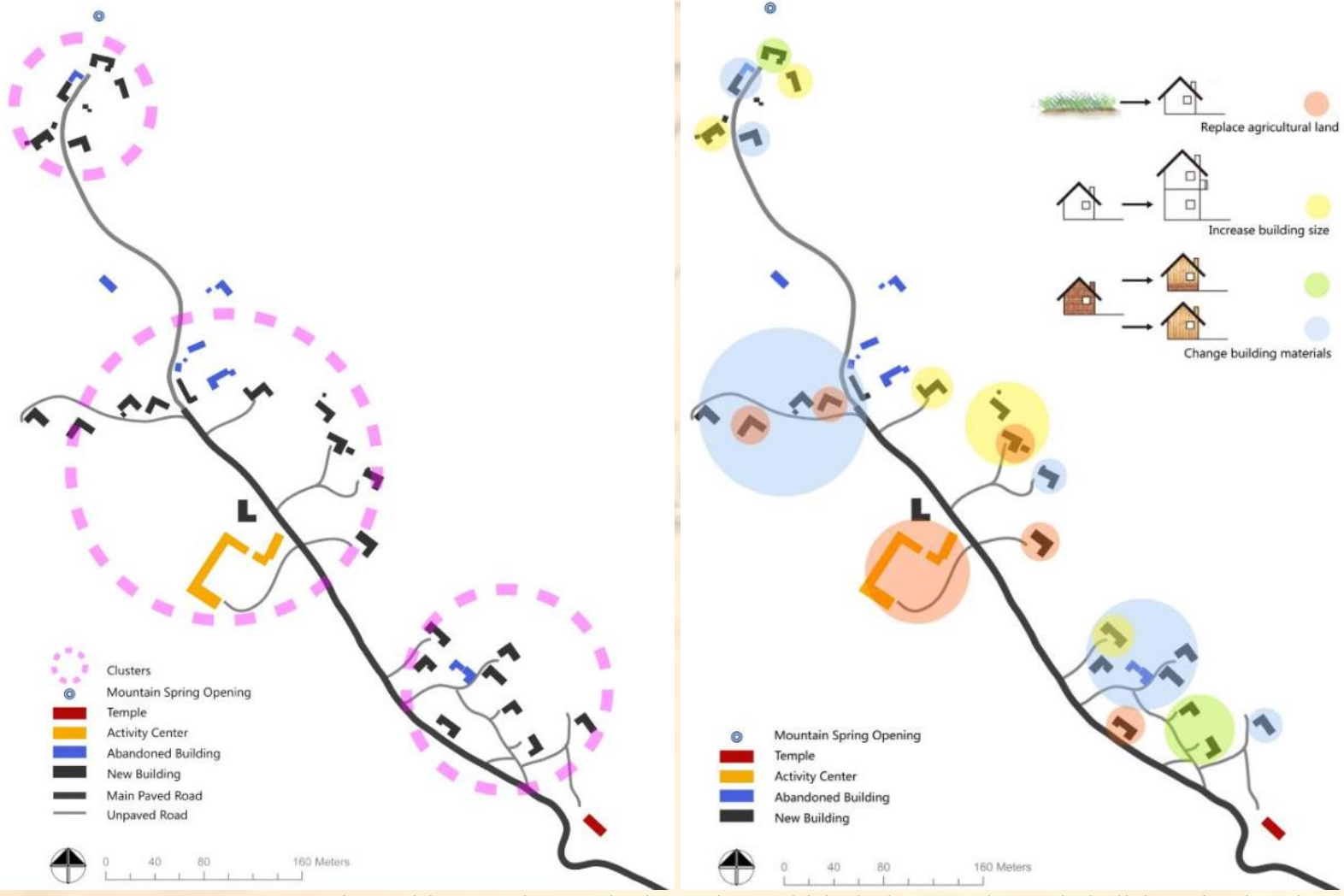

Şekil 13: Da Ping Köyü'nde yeniden yapılması planlanan konut birimleri üç ana kümede belirlenmiş olup, bazı yapılarda da iyileştirme, güçlendirme ve genişletme uygulanmıştır (Werner, 2011). 


\section{Shengli Köyü}

12 Mayıs 2008'deki depremin ardından yeniden inşa çalışma çerçevesine ait ilk plan Ağustos ayında ilan edilmiştir. Buradaki önemli vurgu ise yeniden inşa sürecinin salt bina yapımı olarak değil, uzun vadede bir sosyo-ekonomik kalkınma planı gibi işlenmesi ve gelecek afetlere karşı hazırlık ve afeti önleme gibi prensipleri içermesidir (Chen, 2017). Bunun bir uygulaması olarak ise, yine depremden etkilenen ve merkeze oldukça uzak köylerden biri olan Shengli Köyü örnek verilebilir. Köy, depremden sonra 2000'den fazla sakiniyle adeta bir çadır kent alanına dönmüştü (Philips, 2013). Köyde, yıkılan evlerin yeniden inşasının dışında köy yolunun iyileştirilmesi de hedeflenmiştir. Yıkılan yaklaşık 300 evin yeniden inşası için gereken malzemelerin getirilebileceği düzgün bir yol yoktu. Kâr amacı gütmeyen bir kuruluş desteği ile (Oxfam Hong Kong) köylülerin yapımında çalıştığı ve eskiden olan çamur-toprak karışımı yolun yerine dökme beton olarak yapılan yol, köyün zaman içinde hem tarımsal olarak hem de maddi olarak ilerlemesinin sağlamıştır. Projenin kurumsal sorumlusu olan Tang Fang, yeniden inşa sürecinde yer alan köylülerin, en ufak sorunda bir yetkiliye gitmek yerine artık kendi aralarında toplanıp birlikte kendileri ve köyleri yararına karar alabilme kapasitesine ulaştığını anlatıyor. Yolun yapımı için sağlanan maddi destek yeterli olmadığından köylülerin de katkı sağlaması gerekiyordu. Köylüler başta buna karşı çıksalar da sonuçta bu yolun onların çaresi olacağının farkına vardılar ve gönüllü olarak ücret almadan çalıştılar. 80 kilometrelik yol inşaatında köyden 288 gönüllü günde 14 saat boyunca 69 gün süreyle çalışarak yolu tamamladı (URL 20). Benzer şekilde, köy yolu inşa edilen Jinniu Köyü sakini bir ev kadını ise "Bu yol olursa ürettiğimiz sebzeleri, etleri, tavukları kent merkezine daha kolay ulaştırıp satabileceğiz. Taşıma harcamamız azalacak. O nedenle, gönüllü olarak çalışmaktan mutluyuz" diyerek beklentisini anlatıyor. Yol sayesinde Shengli çevresindeki dağlık bölgede ekilebilir ve otlak arazilere ulaşım kolaylaşmış, bu sayede köylüler, ekin ve hayvan çeşitlerini arttırmışlardır. Öyle ki, deprem öncesinde nüfus kaybeden köy yeniden nüfus kazanmış ve 2016 yılında ülkenin yoksulluk sınırı olan 2300 yuan barajını geçmiş ve 8650 yuan'a ulaşmıştır (URL 21). Ortalama olarak ise, yolun yapılması sonrası köy ekonomisi \%40 büyüme göstermiştir.

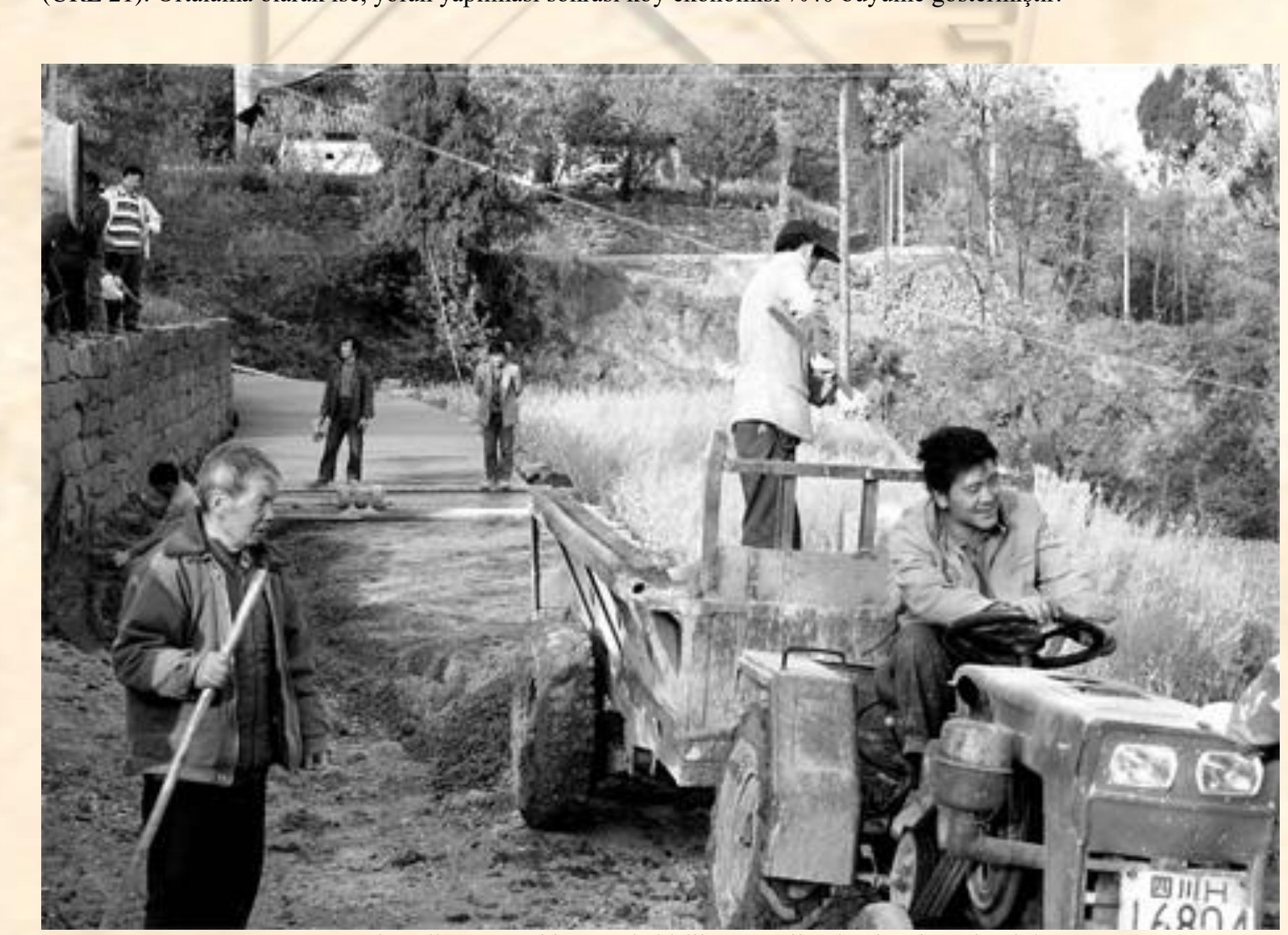

Şekil 13: Shengli Köyü yol inşasında birlikte gönüllü olarak çalışan köylüler (https://www.oxfam.org.hk/filemgr/1031/2_year_on_en.pdf ) 


\section{SONUÇ:}

Şiddetli depremlere maruz kalan Çin için 2008 yılındaki 8 şiddetindeki deprem bir dönüm noktası olmuştur. Resmi olarak kayda geçen yaklaşık 80.000 can kaybının yanında 15 milyon kişi farklı şekillerde felaketten etkilenmiştir. Özellikle dağlık ve uzak kırsal yerleşimlerde kayıplar sayıca az görünse de yıkım büyük olmuş, bu da doğal olarak yoğun bir yeniden inşa ihtiyacı doğurmuştur. Yönetim olarak oldukça merkeziyetçi ve ulusalcı bir yapıda olmasına karşın, 2008 felaketiyle birlikte özellikle kırsaldaki yeniden inşa sürecinde hem yerel yönetimlere daha çok hareket imkânı sunmuş, hem de akademik olan ve kâr amacı gütmeyen organizasyonlarla iş birliğine giderek evlerini kaybeden ve günlük yaşantısı kesintiye uğrayan dar gelirli insanlara nasıl daha iyi bir yapılı çevre sağlayabileceğine ilişkin olarak deneysel uygulamalar yapmaya çalışmıştır. Kang (2015) 2008 Haziran'ından 2010 Ağustos'una kadar başta yerel yönetimlerle yürüttüğü alan çalışmasında bu konuya yer vermekte ve merkeziyetçi ülke yönetiminin böylesi büyük bir afette kırılmalar olmadan başarılı bir afet yönetimi gerçekleştiremeyeceğini deneyimlediğini vurguluyor. Bunun yanında, verilen örneklerde görüldüğü gibi yeniden inşa sürecinin mimari çıktıları pek de alışılagelmiş kırsal konutları andırmamakta, hatta yerleşim planlaması ölçeğinde bakıldığında sanki bir ilçe gibi tasarlandığını görülmektedir. Çin hükümetinin bu yaklaşımı aslında oldukça politik bulunmaktadır. Wilson ve Zang (2018) 2007 yilında Ulusal Kent Planlama Kanunu'nun kırsal bölgeleri de kapsayacak şekilde genişletildiğini ve bunun kırsal yerleşimler için arazi kullanımı, karayolu ulaşım planlaması, kanalizasyon, çöp toplanması ve imhası vb. altyapı çözümleri gibi daha önce üzerinde durulmayan detayları çözmeye odaklandığını yazmıştır. Bunun nedeni olarak da ülkenin Sosyalist kimliğinin (Building of a New Socialist Countryside programı kapsamında) ve şehrin zengin görünümünün kırsala yansıtılabilmesi ve bu sayede kırsalın kente verdiği göçün önüne geçmenin planlanmasını göstermişlerdir. Wang ve Tan (2018), bazı uygulamalarda bu kırsalı kentleştirme politikasının aşırı uçlara vardığını göstermektedir.

2008 depremi Çin halkının hafızasında çok önemli bir yere sahiptir. Bu sadece çok sayıda kayıp verdikleri için değil, aynı zamanda inşaat konusunda kaliteden ve denetimden ödün vererek ne kadar aceleci davrandıklarını sarsıcı resimlerle ortaya koymuştur. Bu deneyimden ders çıkarmak adına Çin devleti yine 'aykırı' bir karar almış ve depremde çok fazla kamu binasının ve okulun yıkıldığı Beichuan beldesini deprem sonrası haliyle bırakarak bir açık hava müzesine çevirmiştir (URL 22; URL 23). Beldedeki afetzedeler ise $30 \mathrm{~km}$ uzaklıktaki yeni bir yerleşim alanına taşınmışlardır (Şekil 14).
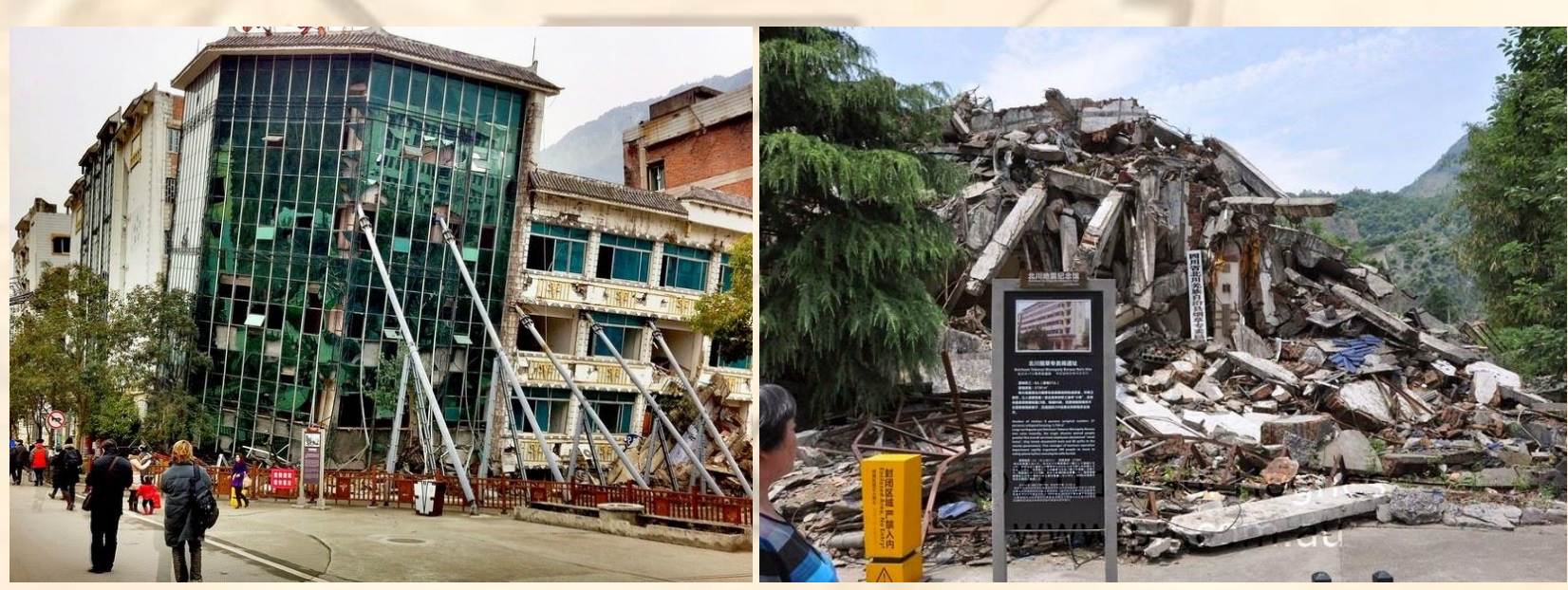

Şekil 14: 2008 Depremi ile açık hava müzesi olarak bırakılan Beichuan Beldesi (https://www.amusingplanet.com/2014/06/beichuan-preserved-ruins-of-earthquake.html).

Benzer şekilde deprem riski altındaki ülkemizde, afet yönetimi ve yeniden inşa aşamaları oldukça kemikleşmiş ve merkezi bir yapıda olup, öncesinde farklı teşkilatlar tarafından yürütülen süreç 2009 yılında çıkarılan 5902 sayılı Afet ve Acil Durum Yönetimi Başkanlığının Teşkilat ve Görevleri Hakkında Kanun ile Afet ve Acil Durum Yönetimi Başkanlığı (AFAD) kurularak tüm yetki ve sorumluluklar tek bir çatı altında toplanmıştır (URL 24). Bunun yerine, yerel yönetimleri ve hem mikro hem de makro organizasyonları iş birliği çerçevesinde sisteme dahil eden, afetten etkilenen kesimin sosyo-ekonomik durumuna göre gelenekseli modernize eden veya tümüyle deneysel-aykırı yaklaşımları getiren, bununla birlikte ekonomik anlamda uzun vadede kalkınmayı hedefleyen bir yeniden yapılaşma modeli tercih edilmelidir. Mevcutta, kırsalda deprem sonrası konutu veya işyeri ağır hasarlı veya yıkık olarak tespit 
edilen afetzedelere, sunulan sınırlı konut modeli içerisinden tercih ettikleri tip, başvurmaları durumunda 2 yıl ertelemeli 20 yıl vadeli borçlandırma yöntemi ile Evini Yapana Yardım (EYY) uygulaması kapsamında maddi yardım yoluyla yapılmaktadır (AFAD, 2014). Ancak, burada uzun vadeli borçlandırma ve borçlandırılan miktar özellikle zaten dar gelirli olan afetzedeler için zorlayıcı bir unsur olmaktadır. Bunun yanında, tip yapılan konutlar bazı kullanıcılarının ihtiyaçlarını karşılamakta yetersiz kalmaktadır (Yılmaz, 2013). Kırsalın kente yenik düştüğü günümüzde, bir deprem sonrası nüfusu hızla verdiği göç nedeniyle eriyen köylerin önüne geçmek imkânsız değil, ancak literatürde 'firsat penceresi' olarak geçen bu durumu, olumluya çevirmek için yer'e ait olan deneysel uygulamalardan ve yeni mimari yaklaşımlardan çekinmemek gerekiyor.

\section{KAYNAKÇA:}

\section{Kitaplar}

AFAD (2014). Müdahale, İyileştirme ve Sosyo-Ekonomik açıdan 2011 Van Depremi, Türkiye Cumhuriyeti Başbakanlık Afet ve Acil Durum Yönetimi Başkanlığı tarafindan hazırlanmıştır. Ankara.

Charlesworth E. (2014). Humanitarian Architecture: 15 stories of architects working after disaster. Routledge.

Chen, Y F (2017). How the Chinese Government Responded to the Wenchuan Earthquake, Chapter 5: Community Engagement in Post-Disaster Recovery. Ed. G. Marsh, I. Ahmed, M. Mulligan, J. Donovan \& S. Barton. Routledge.

Fu, X. (2017). Traditional Chinese Architecture: Twelve Essays, Princeton University Press.

Golden, E M (2017). Building from Tradition: Local Materials and Methods in Contemporary Architecture, Routledge.

Kang, Y. (2015). Disaster Management in China in a Changing Era, Springer.

Knapp, R. G. (2000). China's Old Dwellings, University of Hawaii Press.

\section{Bildiriler}

MU J., NG E., WAN L., ZHOU T., and MA J. Practical Study of the Ecological Rebuilding of Earthquake-Stricken Villages in Southwestern China, PLEA 2011, Conference on Passive and Low Energy Architecture, Louvain-LaNeuve, Belçika, 13-15 Temmuz 2011.

Oxfam Hong Kong's Report Marking the Second Anniversary of the 5.12 Earthquaket: Two Years On, http://www.oxfam.org.hk/filemgr/1031/2_year_on_en.pdf Erişim: 25.01.2018.

\section{Makaleler}

Wang R. ve Tan R. (2018). Rural Renewal of China in the Context of Rural-Urban Integration: Governance Fit and Performance Differences. Sustainability, Vol:10.

Wilson S. ve Xiaorong Z. (2018). "Village Reconstruction in Rural China: The Importance of Being Urban." China Quarterly.

Yllmaz, D. G. (2013). Stories Of Rural People Living In The Settlements Built After Earthquakes: A Case Study From The Province of Van, Turkey. Int. Journal Of Soc.al Sc.ences And Humanity Studies, Vol 5, No 1, 81-91.

\section{Websiteleri}

Aktuelarkeoloji (2018). Deprem Sonrası Guangmıng Köyündeki Yeniden Yapılanma Projesi, http://www.aktuelarkeoloji.com.tr/deprem-sonrasi-guangming-koyundeki-yeniden-yapilanma-projesi $\quad$ Erişim: 22.02.2019. 
URL1: https://tradingeconomics.com/china/rural-population-percent-of-total-population-wb-data.html Erişim: 22.02.2019.

URL2: $\quad$ https://www.archdaily.com/802855/post-earthquake-reconstruction-demonstration-project-of-guangmingvillage-the-chinese-university-of-hong-kong-and-kunming-university-of-science-and-technology Erişim: 20.01.2018.

URL3: http://web5.arch.cuhk.edu.hk/server1/staff1/edward/www/1u1v/files/CUHK/site_Guangming.html_Erişim: 20.01.2018.

URL 4: https://www.dezeen.com/2017/12/01/movie-waf-world-building-of-year-winner-earthquake-resistant-video/ Erişim: 20.01.2018.

URL 5: Prof. NG, Yan Yung Edward akademik sayfası: http://www.arch.cuhk.edu.hk/person/ng-yan-yung-edward/ Erişim: 20.01.2018.

URL 6: https://www.archdaily.com/883888/guangming-post-earthquake-reconstruction-project-wins-world-buildingof-the-year-2017 Erişim: 20.01.2018.

URL7:https://www.architectural-review.com/today/ar-house-winners-revealed/10021150.article?blocktitle=NEWSAR-House-winners\&contentID=19048 Erişim: 20.01.2018.

URL 8: http://www.rufwork.org/index.php?/project/jintai-village/ Erişim: 20.01.2018.

URL 9: https://www.dezeen.com/2017/10/21/rural-urban-framework-builds-post-disaster-housing-china-rooftopfarms/ Erişim: 20.01.2018.

URL 10: http://edition.cnn.com/style/article/rural-urban-framework-innovative-design/index.html Erişim: 20.01.2018.

URL 11: https://www.treehugger.com/green-architecture/rural-urban-frameworks-post-disaster-housing-rooftopfarms.html Erişim: 20.01.2018.

URL 12: http://currystonedesignprize.com/winners/hsieh-ying-chun/Erişim: 21.01.2018.

URL 13: http://currystonedesignprize.com/2011-curry-stone-design-prize-winners-announced/Erişim: 21.01.2018.

URL 14: https://www.architectureforpeople.org/architects/hsieh-ying-chun/Erişim: 21.01.2018.

URL 15: https://www.architecturalrecord.com/articles/8521-yangliu-village-housing?v=preview Erişim: 21.01.2018.

URL 16: https://archinect.com/hsiehyingchun/project/postearthquake-reconstruction-yang-liu-village Erişim: 21.01.2018.

URL 17: https://www.domusweb.it/en/architecture/2012/04/10/back-to-earth.html Erişim: 21.01.2018.

URL 18: http://web5.arch.cuhk.edu.hk/server1/staff1/edward/www/1u1v/files/fraternity/maanqiao.html Erişim: 21.01.2018.

URL 19: https://www.world-habitat.org/world-habitat-awards/winners-and-finalists/sustainable-village-postearthquake-reconstruction-and-rehabilitation-in-da-ping-village-sichuan/\#award-content Erişim: 22.01.2018.

URL 20: http://www.acyf.org.cn/2010-02/10/content_3380907.htm Erişim: 25.01.2018.

URL 21: http://www.chinadaily.com.cn/china/2017-07/11/content_30064936_2.htm Erişim: 25.01.2018.

URL 22: https://www.theatlantic.com/photo/2018/05/10-years-since-the-devastating-2008-sichuanearthquake/560066/ Erişim: 25.02.2019 
URL 23: https://www.amusingplanet.com/2014/06/beichuan-preserved-ruins-of-earthquake.html Erişim: 25.02.2019

URL 24: https://www.afad.gov.tr/tr/2211/AFAD-Hakkinda Erişim: 24.02.2019

Philips, T (2013). China earthquake: family buries boy by roadside as region mourns dead, https://www.telegraph.co.uk/news/worldnews/asia/china/10008644/China-earthquake-family-buries-boy-by-roadsideas-region-mourns-dead.html Erişim: 24.02.2019

XXI (2016). Kırsalın Geri Kazanımı, https://xxi.com.tr/i/kirsalin-geri-kazanimi Erişim: 23.01.2018

Werner V. (2011). Post-Earthquake Reconstruction in Daping Village: Reconstruction On Orıginal Sites, https://issuu.com/virginia.werner/docs/dapingreportwernerlauhe-final Erişim: 24.02.2019

\section{Gerekli İlave Kaynakça Listesi}

China Perspectives, Special Features (2013). Vol:2. Ed: Hillman B. ve Unger J. OpenEdition Journals

Villages in the City: A Guide to South China's Informal Settlements (2014). Ed: Stefan Al, Paul Chu Hoi Shan, Claudia Juhre, Ivan Valin, Casey Wang Hong Kong University Press.

Wan L. (2013). Study of Built Environmental Sustainability Assessment of Poor Rural Areas of Southwest China. Doctor of Philosophy in Architecture (Yayınlanmamış Doktora Tezi). The Chinese University of Hong Kong. 